\title{
Potensi Kepiting Bakau (Scylla Spp) Pada Ekosistem Mangrove Di Kota Bengkulu
}

\author{
Oktamalia $^{1}$, Enggar Apriyanto ${ }^{2}$, Dede Hartono ${ }^{3}$ \\ ${ }^{1}$ Mahasiswa Program Studi Pengelolaan Sumber Daya dan Lingkungan, Universitas Bengkulu \\ ${ }^{2}$ Dosen Program Studi Kehutanan Fakultas Pertanian, Universitas Bengkulu \\ ${ }^{3}$ Dosen Program Studi Ilmu Kelautan, Fakultas Pertanian, Universitas Bengkulu
}

\begin{abstract}
ABSTRAK
Kepiting bakau merupakan salah satu komoditas perikanan yang memiliki potensi sebagai penyangga kehidupan masyarakat terutama bagi nelayan sekala kecil. Ekosistem mangrove mempunyai peran penting sebagai habitat utama bagi kepiting bakau(Scylla Spp). Penelitian tentang potensi kepiting bakau (Scylla spp) pada ekosistem mangrove guna mengetahui kondisi populasi kepiting bakau di alam sehingga dapat menjadi acuan dalam mengatur penangkapan dan sebagai landasan kebijakan pengelolaan penangkapan kepiting bakau untuk menjamin usaha penangkapan kepiting bakau secara berkelanjutan dan berkesinambungan. Penelitian ini berdasarkan 3 jenis kerapatan mangrove, setiap stasiun dibagi menjadi 3 transek garis dengan masing-masing 4 plot (ukuran 10x10 m) tiap transek garis. Tiap plot di pasang bubu sebanyak 2 buah pada setiap minggu selama 4 bulan (Juli-Oktober). Hasil pada ekosistem mangrove di Kota Bengkulu memiliki potensi kepiting bakau sebanyak 1.183 ekor. Secara keseluruhan habitat kepiting bakau pada perairan kota bengkulu sangat mendukung dalam menunjang kehidupan kepiting bakau dengan keberadaan kerapata mangrove jarang, sedang dan rapat yang memiliki 7 jenis mangrove yaitu yaitu R.apiculata,S.alba, B.gymnoriza, A.lanata, X.Granatum, K.candel dan L. littoreae. Memiliki kisaran parameter fisika kualitas air suhu $-29,25^{\circ} \mathrm{C}$, salinitas $11-26,25^{\circ} \%$, $\mathrm{pH} 6,95-7,55$ pasang tertinggi 80 $106,25 \mathrm{~cm}$ dan kandungan C-Organik 4,18-5,83\%. Hubungan total tangkapan kepiting dengan kerapatan mangrove dan Hubungan total tangkapan kepiting dengan kandungan C-organik pada sedimen masing-masing kedua variabel memiliki pengaruh hubungan yang kuat dengan nilai koefisien determinasi $\left(\mathrm{R}^{2}\right)$ sebesar $80 \%$ dan $90 \%$.nilai koefieien korelasi (r) di peroleh 0,89 dan 0,95 .
\end{abstract}

\section{Kata Kunci: Potensi Kepiting Bakau, Ekosistem Mangrove,}

\section{PENDAHULUAN}

Kepiting bakau merupakan salah satu komoditas perikanan yang memiliki potensi sebagai penyangga kehidupan masyarakat terutama bagi nelayan sekala kecil (small scale fisheries). Kepiting bakau termasuk sumberdaya perikanan pantai yang mempunyai nilai ekonomis penting dan mempunyai harga yang mahal. Jenis kepiting ini disenangi masyarakat karena bernilai gizi tinggi dan mengandung berbagai nutrien penting (Kanna, 2002). Kordi (2000) menyatakan bahwa setiap $100 \mathrm{~g}$ daging kepiting bakau (segar), mengandung 13,6 g protein, 3,8 g lemak, $14,1 \mathrm{~g}$ hidrat arang dan $68,1 \mathrm{~g}$ air, sedangkan Motoh (1977), menyatakan bahwa daging dan telur kepiting bakau (dalam berat kering) mengandung protein yang cukup tinggi $(67,5 \%)$ dan kandungan lemak yang relatif rendah $(0,9 \%)$. Menurut Kanna (2002) selain memiliki nilai ekonomis yang tinggi. Kepiting bakau merupakan salah satu komoditas andalan untuk ekspor. Negara tujuan ekspor antara lain Amerika Serikat, Jepang, Australia, Benelux, Hongkong, Taiwan, Singapura, Korea Utara dan Korea Selatan.

Ekosistem mangrove merupakan salah satu ekosistem berperan penting di wilayah pesisir Indonesia. Ekosistem mangrove ini memiliki banyak fungsi mendasar yang mampu mendukung kehidupan manusia maupun biota-biota yang berada di sekitarnya. Secara ekologis ekosistem mangrove ini berfungsi sebagai 
daerah memijah, daerah mencari makan serta daerah asuhan bagi berbagai macam organisme yang mempunyai nilai ekonomis seperti ikan, kerang, kepiting, dan udang (Bengen, 2002).

Ekosistem mangrove di pesisir Kota Bengkulu baik yang berada di dalam kawasan hutan Taman Wisata Alam Pantai Panjang-Pulau Baii maupun yang berada di luar kawasan hutan terdapat salah satu komoditas perikanan pesisir yang belum dikelola secara optimal dengan baik yaitu salah satunya Kepiting Bakau (Scylla spp). Usaha penangkapan kepiting bakau pada ekosistem mangrove di Kota Bengkulu ini masih bersifat tradisional dan terfokus pada aktivitas penangkapan di alam, yang masih sangat tergantung kepada stok yang tersedia di alam.

Untuk menghindari pemanfaatan kepiting bakau secara berlebihan yang mengakibatkan penurunan populasi kepiting bakau di alam pada ekosistem mangrove di Kota Bengkulu maka perlu adanya penelitian tentang potensi kepiting bakau (Scylla spp), informasi biologi kepiting bakau mengenai (jenis kepiting, jenis kelamin, kelas, fase kehidupan kepiting, kandungan bahan organik dalam sedimen perairan dan parameter fisika kualitas air), hubungan total tangkapan kepiting dengan kerpatan mangrove, hubungan total tangkapan kepiting dengan kandungan C-organik sehingga dapat menjadi acuan dalam mengatur penangkapan dan sebagai landasan kebijakan pengelolaan penangkapan kepiting bakau untuk menjamin usaha penangkapan kepiting bakau secara berkelanjutan dan berkesinambungan.

Penelitian ini dilakukan dengan tujuan untuk mengetahui potensi kepiting bakau (Scylla spp) pada ekosistem mangrove di Kota Bengkulu, menganalisis kualitas lingkungan habitat kepiting bakau (Scylla spp) pada ekosistem mangrove di Kota Bengkulu menganalisis hubungan kerapatan pohon mangrove dengan kepiting baka, hubungan kandungan $\mathrm{C}$ organik dengan kepiting bakau pada ekosistem mangrove di Kota Bengkulu.

\section{METODE PENELITIAN \\ Waktu dan Tempat Penelitian}

Penelitian ini telah dilaksanakan pada ekosistem mangrove di Kota Bengkulu. Penelitian dilakukan kurang lebih selama 4 (empat) bulan yaitu pada bulan (Juli Oktober) 2017.

\section{Alat dan Bahan Penelitian}

$\begin{array}{llr}\text { Alat yang digunakan } & \text { dalam } \\ \text { penelitian ini } & \text { adalah } & \text { Bubu } \\ \text { lipat,Ember,Alat tulis menulis, } & \text { Buku } \\ \text { identifikasi kepiting, Kamera digital, }\end{array}$
Meteran roll, GPS receiver, Termometer $\mathrm{Hg}$, Hand Refraktometer, $\mathrm{pH}$, Peralon, Perahu, Papan berskala.Alat yang dipakai di laboraturium adalah Cawan penguapan, Oven, Timbangan analiti (Sartorius dengan ketelitian 0,0001), kertas whattman ukuran $45 \mu \mathrm{m}$. Bahan Penelitian adalah Label,Tisu, Pancang, Kantong plastik, Tali raffia, Kepiting dan mangrove dan Ikan rucah.

\section{Metode Penelitian}

Penelitian ini menggunakan metode survei dengan menggunakan teknik observasi langsung, simple ramdom sampling (pengambilan secara acak) untuk kepiting bakau dan pengamatan vegetasi mangrove. Penangkapan kepiting bakau (Scylla spp) dilakukan 16 kali selama 4 bulan yaitu pada bulan Juli- Oktober (2017). dengan menggunakan alat tangkap berupa bubu lipat yang berukuran diameter tinggi $13 \mathrm{~cm}$ lebar $30 \mathrm{~cm}$ panjang $55 \mathrm{~cm}$. Pada setiap pengamatan ditetapkan transek garis dari arah laut ke arah darat tegak lurus garis pantai sepanjang zonasi ekosistem mangrove identifikasi mangrove mengacu pada panduan pengenalan magrove oleh Noor $d k k$ (2006). Pada setiap kerapatan mangrove terdapat 3 garis setiapgaris terdapat 4 plot yang berukuran 10 x 10 m.Pengukuran Parameter FisikaKimia secara in situ. Analisis sampel sedimendi laboratorium Tanah Universitas Bengkulu. 


\section{Kerangka Berpikir Penelitian}

Secara singkat keranga berfikir mengenai potensi kepiting bakau (Scylla spp) pada ekosistim mangrove di Kota Bengkulu dapat dilihat di gambar 1.

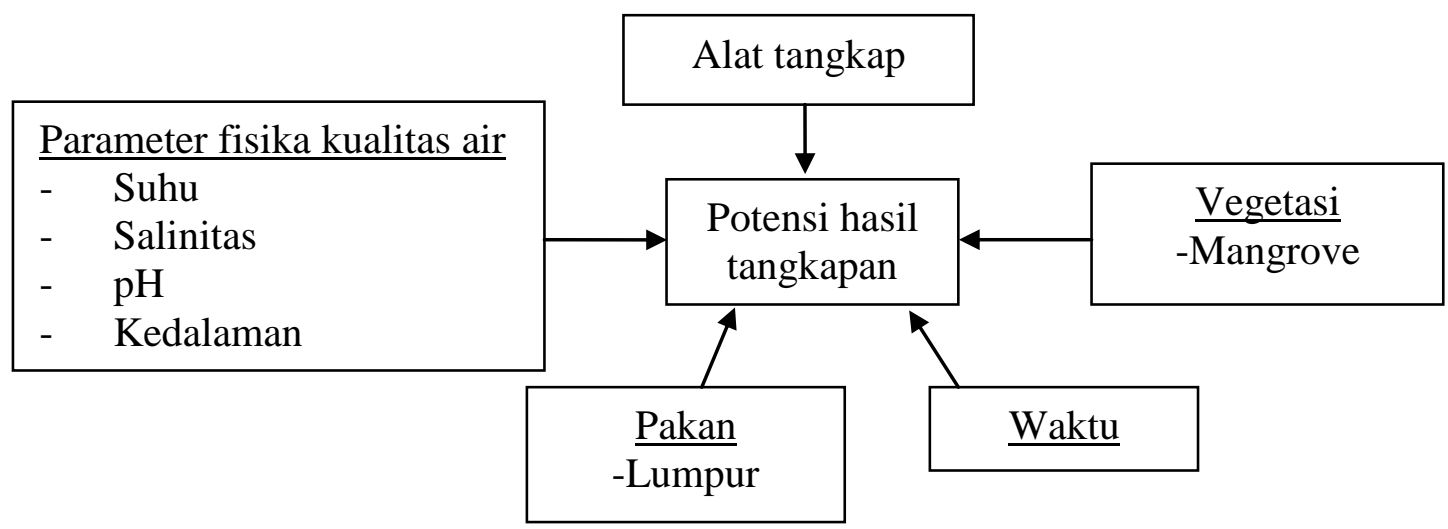

Gambar 1. Diagram Alir Penelitian

\section{Analisis Data}

\section{Identifikasi Jenis Kepiting Bakau dan Mangrove}

Identifikasi jenis kepiting bakau menggunakan pedoman identifikasi jenis ikan dan kepiting bakau (Keputusan Badan Karantina Ikan pengendalian mutu dan keamanan hasil perikanan nomor 67/ KEPBKIPM / 2016), sedangkan untuk identifikasi mangrove menggunakan Panduan Pengenalan Mangrove oleh Noor $d k k$. (2006).

\section{Densitas/Kerapatan Mangrove}

Densitas merupakan jumlah individu organisme per satuan luas. Untuk kepentingan analisis komunitas tumbuhan, istilah densitas digunakan dengan istilah kerapatan dan diberi notasi $\mathrm{K}$.

$$
\mathrm{K}=\frac{\text { jumlah individu }}{\text { luas seluruh petak plot }}
$$

\section{Analisis Kandungan Bahan Organik Pada Sedimen Perairan}

Untuk mengetahui kandungan bahan organik total dalam sedimen dilakukan perhitungan menurut Pett (1993), dengan rumus sebagai berikut:

Bahan sedimen organik

$$
=\frac{(d-a)}{c} \times 100 \%
$$

Dimana:

$$
\mathrm{d}=\text { Berat cawan dan sampel dan setelah }
$$
pengeringan $105^{\circ} \mathrm{C}$ $\mathrm{a}=$ Berat cawan sampel setelah pembakaran $550^{\circ} \mathrm{C}$

$\mathrm{c}=$ Berat sampel awal (mg)

Menurut Hardjowigeno (2003), sifat kimia tanah berdasarkan kandungan C-organik terbagi menjadi lima yaitu:

1. $(<1,00 \% \mathrm{C})=$ Sangat rendah

2. $(1,00-2,00 \% \mathrm{C})=$ Rendah

3. $(2,01-3,00 \% \mathrm{C})=$ Sedang

4. $(3,01-5,00 \% \mathrm{C})=$ Tinggi dan

5. $(>5,00 \% \mathrm{C}) \quad=$ Sangat tinggi

\section{Hubungan Antara Hasil Tangkap Kepiting Bakau Dengan Kerapatan Pohon Mangrove}

Untuk melihat hubungan antara dua variabel ( $\mathrm{x}$ dan y) yang berbeda, dilakukan pengujian analisis uji korelasi jenis Product Moment $\left(\mathrm{r}_{\mathrm{xy}}\right)$. Dari hasil hubungan antara dua variabel ( $x$ dan $y$ ) yang berbeda, dilakukan pengujian model regresi sederhana. Rumus yang digunakan adalah:

$$
\mathrm{Y}=\mathrm{a}+\mathrm{b} \mathrm{x}
$$

Keterangan: $\mathrm{Y}=$ Jumlah tangkapan kepiting bakau $\mathrm{x}=$ Kerapatan pohon mangrove $\mathrm{a}=$ Konstanta $\mathrm{b}=$ slope

Keeratan hubungan antara hasil tangkap kepiting bakau dengan kerapatan pohon dan produktivitas sedimen dapat dilihat dari besarnya koefisien korelasi (r) dan koefisiens determinasi (R2). Nilai 
koefisien korelasi berkisar -1 sampai +1 , tanda negative (-) menyatakan korelasi negative dan tanda positif (+) menyatakan korelasi positif. Nilai koefisien determinasi berkisar antara 0 sampai 1 . Koefisien determinasi menggambarkan besarnya variasi indeks tetap (y) dapat diterangkan oleh indeks bebas (x), sedangkan koefisien korelasi menggambarkan besarnya hubungan antara indeks bebas dengan indeks tetap.

\section{Hubungan Antara Hasil Tangkap} Kepiting Bakau Dengan Kandungan Bahan Organik Pada Sedimen Perairan

Untuk melihat hubungan antara dua variabel (x dan y) yang berbeda, dilakukan pengujian analisis uji korelasi jenis Product Moment $\left(\mathrm{r}_{\mathrm{xy}}\right)$. Dari hasil hubungan antara dua variabel ( $x$ dan $y$ ) yang berbeda, dilakukan pengujian model regresi sederhana. Rumus yang digunakan adalah:

$$
\mathrm{Y}=\mathrm{a}+\mathrm{bx}
$$

Keterangan : $\mathrm{Y}=$ Jumlah hasil tangkapan kepiting bakau

$$
\mathrm{x}=\text { Kandungan Bahan }
$$

Organik Pada Sedimen Perairan

$$
\begin{aligned}
& \mathrm{a}=\text { Konstanta } \\
& \mathrm{b}=\text { slope }
\end{aligned}
$$

Keeratan hubungan antara hasil tangkap kepiting bakau dengan Kandungan Bahan Organik Pada Sedimen Perairan dapat dilihat dari besarnya koefisien korelasi (r) dan koefisiens determinasi (R2). Nilai koefisien korelasi berkisar -1 sampai +1 , tanda negative (-) menyatakan korelasi negative dan tanda positif $(+)$ menyatakan korelasi positif. Nilai koefisien determinasi berkisar antara 0 sampai 1. Koefisien determinasi menggambarkan besarnya variasi indeks tetap (y) dapat diterangkan oleh indeks bebas (x), sedangkan koefisien korelasi menggambarkan besarnya hubungan antara indeks bebas dengan indeks tetap.

\section{HASIL DAN PEMBAHASAN \\ 4.1.1 Ekosistem Mangrove}

Berdasarkan hasil pengamatan di lokasi penelitian kerapatan jenis pohon mangrove yang ditemukan dapat dilihat pada (Gambar 2). Jenis pohon mangrove yang ditemukan pada ke tiga kerapatan mangrove terdapat 7 jenis yaitu R.apiculata,S.alba, B.gymnoriza, A.lanata, X.Granatum, K.candel dan $L$. littoreae.Tingginya kerapatan pohon mangrove jenis A.lanatayang ditemukan pada kerapatan jarang karena dasar perairan yang berpasir dan gundukan tanah jenis pohon ini dapat mentolerir meskipun kandungan unsur hara nya sedikit. Rendahnya kerapatan pohon mangrove jenis L.littoreae di karenakan jenis pohon ini lebih menyukai dasar perairan yang berpasir dan berlumpur.Tingginya vegetasi mangrove jenisR.apiculatayang ditemukan pada kerapatan mangrove sedang dan rapat karena pada ke dua kerapatan mangrove ini memiliki dasar perairan yang berpasir dan berlumpur. Menurut Noor dkk (2006) pada ekosistem yang tanahnya berpasir dan berlumpur umumnya di dominasi oleh jenis Avicennia sp dan Rhizophora sp. Rendahnya kerapatan vegetasi mangrove jenis X.GranatumK.candelpada kerapatan mangrove sedang dan rapat di karenakan

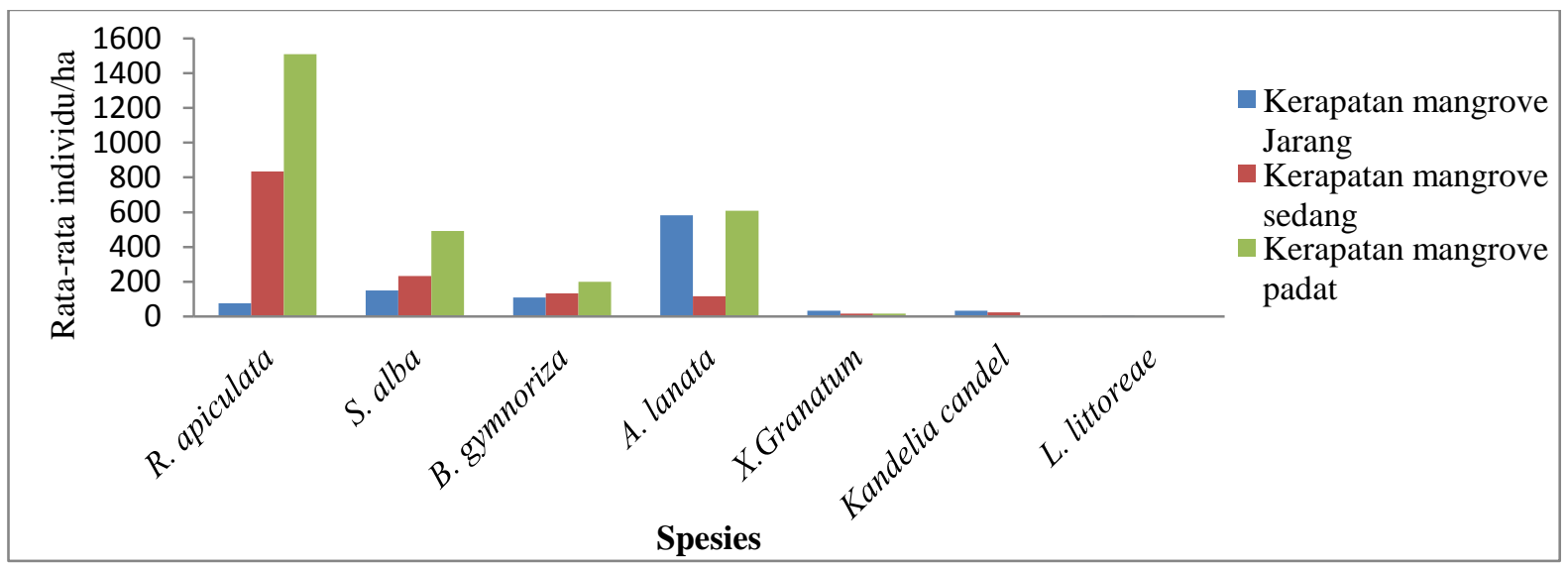

Gambar 2. Kerapatan jenis pohon mangrovepada ekosistem mangrove di Kota Bengkulu. 
jenis ini lebih menyukai dasar perairan yang berpasir dan berlumpur.Menurut KEPMEN_LH Nomor 201 tahun (2004) kreteria kerapatan pohon mangrove sangat padat > 1500 (pohon/ha), kreteria kerapatan pohon mangrove sedang $>1000$ 1500 (pohon/ha) dan kreteria kerapatan pohon mangrove jarang < 1000 (pohon/ha).

\section{Potensi Kepiting Bakau (Scylla spp)}

Berdasarkan hasil identifikasi potensi kepiting bakau (Scylla spp)pada lokasi penelitian ditemukan 3 jenis kepiting yang termasuk ke dalam Famili Portunidae Kelas Crustasea, Ordo Decapoda dan 3 spesies, Scylla serrata, Scylla olivacea dan Scylla tranquibarica. Selain di perairan Kota Bengkulu, ke tiga spesies ini juga ditemukan di Pulau Enggano Provinsi Bengkulu Herliany dkk (2015). Menurut Keenan dkk (1998) pada beberapa perairan di Indonesia jenis S.serrata, S.olivacea dan S.tranqueberika juga dapat ditemukan di utara jawa, selatan jawa dan di wilayah Papua. Tiga jenis ini juga di temukan Dalam penelitian Miswar (2000) yang dilakukan di Suaka Margasatwa Karang Gading, Sumatra utara, Pary (2010) di Maluku dan
Hendrarto (2012) di Kandal, Semarang, Bonang, Wedung dan Rembang.

Perairan pada ekosistem mangrove di Kota Bengkulu merupakan daerah yang cukup potensial dengandaya dukung keberadaan hutan mangrove yang tergolong jarang, sedang dan rapat,memiliki kisaran parameter fisika kualitas air, suhu $28-29,25^{\circ} \mathrm{C}$, salinitas 11 $26,25^{\circ} \%$, $\mathrm{pH} 6,95-7,55$ pasang tertinggi 80 $106,25 \mathrm{~cm}$ dan kandungan C-Organik 4,18$5,83 \%$ yang sangat mendukung kehidupan kepiting bakau. Menurut Cholik (1999) menyatakan suhu yang baik untuk pertumbuhan kepiting bakau yaitu berkisar $28-33^{0}$ C. Salinitas yang baik untuk menunjang pertumbuhan kepiting bakau yaitu berkisar $15-26,25^{\circ} \%$. perairan yang meiliki kisaran $\mathrm{pH}$ 6,50-7,50 dikatagorikan perairan yang cukup baik bagi kepiting bakau (Scylla spp) (Siahainenia, 2008). Menurut Setiawan dan Triyanto (2012), bahwa karakteristik fisik yang sangat sesuai memiliki potensi yang besar sebagai tempat hidup, sebagai lokasi penangkapan dan dapat dijadikan daerah pengembangan budidaya kepiting bakau.Jenis dan jumlah individu kepiting yang ditemukan pada setiap stasiun dapat dilihat pada (Gambar $3)$.

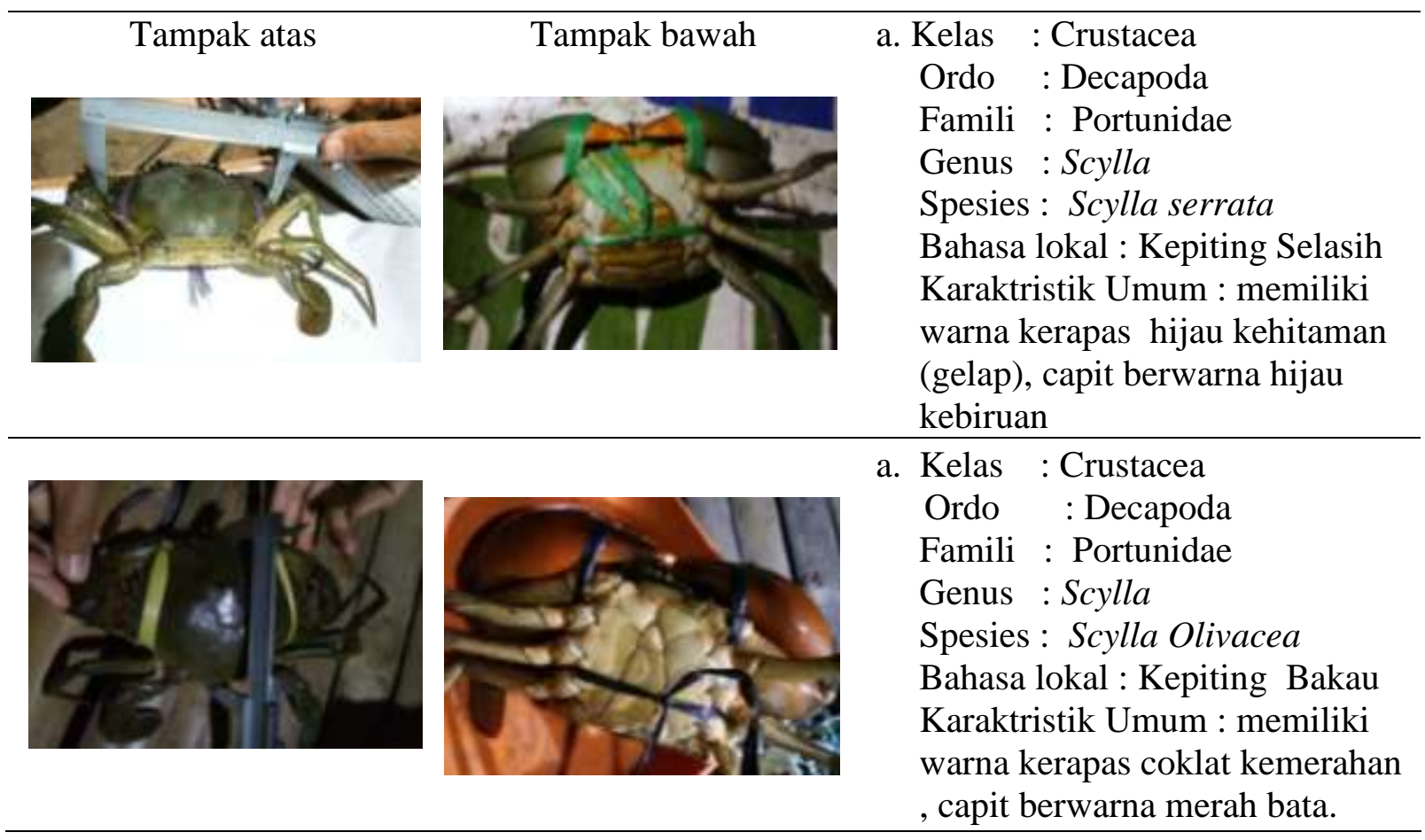



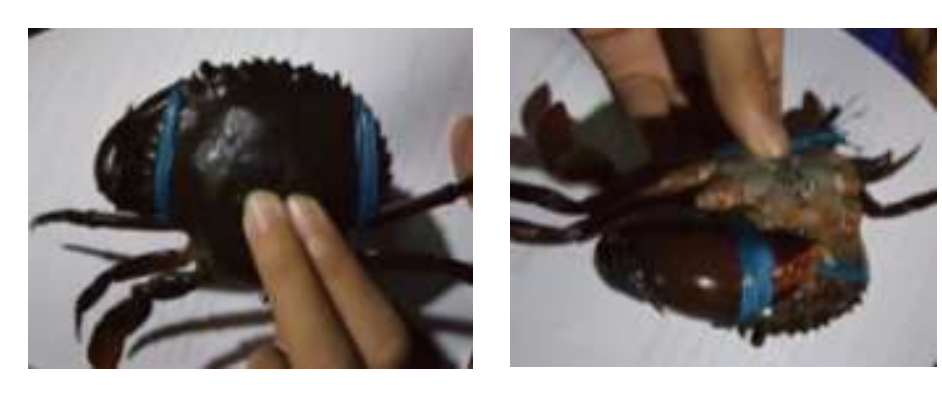

b. Kelas : Crustacea

Ordo : Decapoda

Famili : Portunidae

Genus : Scylla

Spesies : Scylla tranquibarica

Bahasa lokal : Kepiting Hijau

Karaktristik Umum : memiliki

warna karapas kecoklatan dan

hijau tua kehijauan sampai

kehitaman dengan sedikit garis -

garis berwarna kecoklatan pada

kaki renangnya.

Gambar 3. Jenis Kepiting yang ditemukan pada ekosistem mangrove di Kota Bengkulu.

Tabel 1.Potensi keseluruhan individu kepiting bakau yang ditangkap pada setiap kerapatan mangrove di perairan ekosistem mangrove di Kota Bengkulu.

selama bulan Juli-Oktober 2017).

\begin{tabular}{|c|c|c|c|c|}
\hline \multirow[b]{2}{*}{$\begin{array}{l}\text { Kerapatan } \\
\text { mangrove }\end{array}$} & \multicolumn{3}{|c|}{ Jumlah dan Jenis Individu Kepiting Bakau (Ekor) } & \multirow{2}{*}{$\begin{array}{l}\text { Total Kepiting } \\
\text { (Ekor) }\end{array}$} \\
\hline & Scylla olivacea & Scylla serrata & Scylla tranquebarika & \\
\hline Jarang & 74 & 180 & 6 & 260 \\
\hline Sedang & 108 & 280 & 17 & 405 \\
\hline Rapat & 122 & 389 & 7 & 518 \\
\hline Jumlah & 304 & 849 & 30 & 1.183 \\
\hline
\end{tabular}

Hasil pengamatan dilapangan yang telah dilakuan sejak bulan Juli hingga bulan Oktober Tahun 2017 menunjukkan bahwa pada ekosistem mangrove di Kota Bengkulu memiliki potensi sebagai habitat kepiting bakau.

Tingginya kepiting jenis Scylla serrata yang ditemukan pada kerapatan mangrove rapat karena dasar perairan yang berlumpur merupakan faktor penyebab utama kehadiran kepiting bakau, karena terjaminnya ketersediaan makanan Suryani (2006). Kepiting bakau biasanya lebih menyukai tempat yang agak berlumpur dan berlubang-lubang di daerah hutan mangrove. Berdasarkan observasi pada kerapatan mangrove rapat banyak di tumbuhi vegetasi jenis mangrove rhizophora yang mampu menahan subtrat lumpur lebih banyak dan membentuk tutupan perakaran yang padat yang berfungsi menyaring kandungan bahan organik sehingga pada kerapatan mangrove rapat ini sangat di senangi kepiting bakau selain untuk mencari makan tempat berlindung

dari serangan predator.Rendahnya jumlah individu dan jenis kepiting S.tranquebarikasecara keseluruhan pada kerapatan mangrove jarang di pengaruhi beberapa faktor yaitu karena kerapatan mangrove yang tergolong jarang, letak topografi lebih tinggi dibanding kerapatan mangrove sedang dan rapat sehingga saat pasang surut tidak tergenang lama dan air meninggalakan stasiun lebih cepat. Adanya aktivitas warga seperti alih fungsi kawasan hutan mangrove menjadi area pertambakan dan pemukiman sehinggga kerapatan mangrove berkurang yang menyebabkan berkurangnya sumber makanan. Menurunnya populasi kepiting bakau di alam dapat disebabkan oleh kerusakan ekosistem mangrove sebagai habitat alami kepiting bakau (Triyanto et al., 2013 dan Siahainenia 2008).

\section{Total Tangkapan Ke 3 Jenis Kepiting} (S.olivacea, S.serrata dan 


\section{S.tranquebarica) Berdasarkan Jenis Kelamin dan Fase Kepiting.}

Total tangkapan ke 3 jenis kepiting (S.olivacea, S.serrata dan S. tanquebarica) berdasarkan jenis kelamin dan fase kepiting dengan kerapatan pohon mangrove jarang, sedang dan rapat yang telah dilakukan selama 4 bulan yaitu bulan Juli- Oktober tahun (2017) dapat dilihat pada Gambar 4.

Tingginyatotal tangkapan kepiting bakaufase muda pada kerapatan pohon mangrove rapat baik jenis kepiting S.olivacea, S.serrata dan S.tranquebarikapada fase muda kepiting muda dari laut menyusuri perairan pantai, sungai dan kembali lagi menaungi perairan ekositem mangrove untuk melangsungkan kehidupannya.Menurut Kasry (1996) bahwa ekosistem mangrove, merupakan tempat ideal bagi kepiting bakau untuk berlindung.Kepiting bakau pascalarva, muda yang berasal dari laut banyak dijumpai di sekitar estuari dan hutan mangrove, karena terbawa arus dan air pasang dan akan menetap di daerah perairan sekitar tambak dan hutan mengrove untuk berlindung dan membesarkan diri.Rendahnya total tangkapan kepiting bakau pada fase dewasa di kerapatan pohon mangrove sedang baik jenis kepiting S.olivacea, S.serrata dan S.tranquebarika disebabkan oleh penangkapan kepiting yang dilakukan secara terus menerus di alam oleh nelayan tanpa memperhatikan ukuran tangkap yang sudah di atur Seperti yang di atur dalam surat edaran Mentri kelautan dan perikanan No 18/MEN-KP/1/2015 tentang pengakapan kepiting bakau (Scylla spp)

A

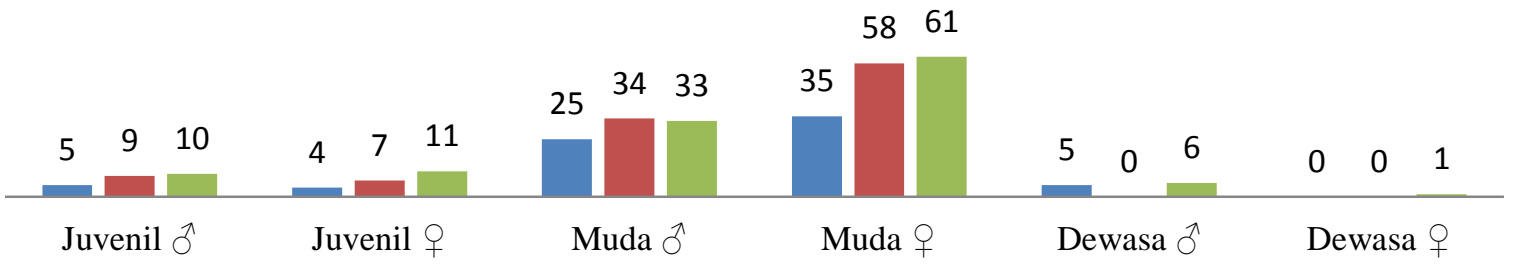

B

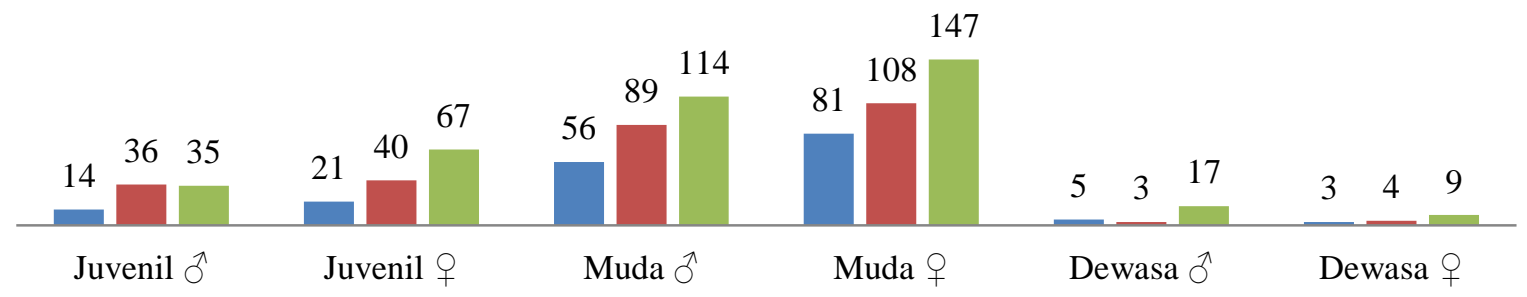

C

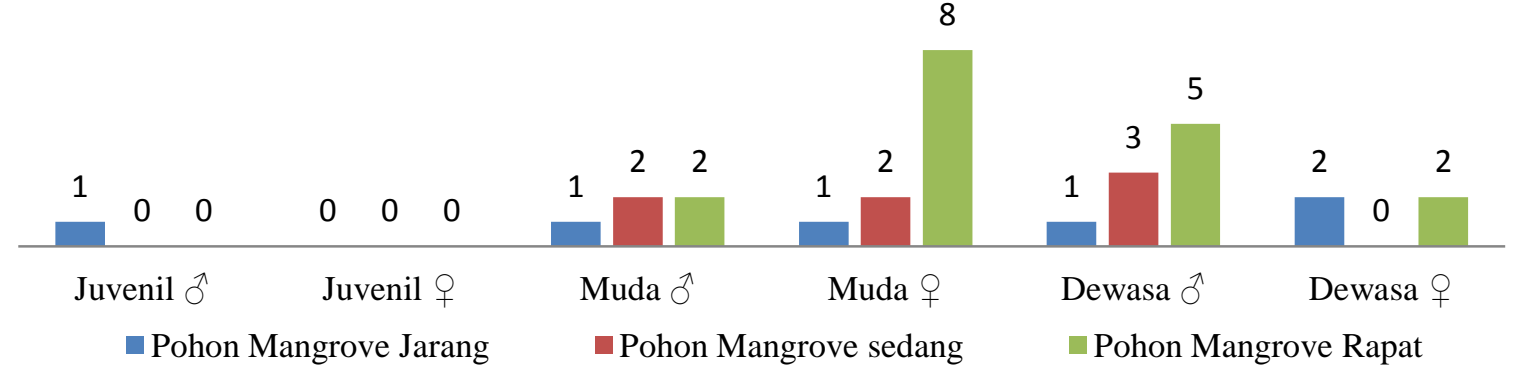

Gambar 4. Grafik total tangkapan jenis kepiting S.olivacea(A) total tangkapan jenis kepitingS.serrata(B) total tangkapan jenis kepiting S. tanquebarica) (C). Dengan kerapatan pohon mangrove jarang, sedang dan rapat. 
dan ranjungan (Portunus spp) bahwa sejak januari 2015 ukuran berat kepiting bakau yang boleh di tangkap lebih dari 200 gram (>200 g).

Pada fase dewasa kepiting bakau banyak tertangkap berjenis kelamin jantan dibanding kepiting bakau berjenis kelamin betina hal ini di sebabkan karena kepiting bakau betina kembali lagi menyusuri perairan laut dan meninggalkan perairan hutan mangroveuntuk mencari perairan yang parameter lingkungannya (terutama suhu dan salinitas perairan) cocok, sebagai tempat memijah. Sedangkan kepiting jantan dewasa tetap menaungi perairan hutan mangrove.Hill (1975) bahwa dominasi jantan dapat terjadi karena adanya pola migrasi padakepiting bakau. Kepiting bakau melangsungkan perkawinan di perairan mangrove dan secara berangsurangsursesuai dengan perkembangan telurnya, kepiting betina akan beruaya (berenang) ke laut danmemijah, sedangkan kepiting jantan tetap di perairan hutan bakau atau muara sungai.

\section{Hubungan Total Tangkapan Kepiting Bakau Dengan Kerapatan Pohon Mangrove.}

Hubungan antara total tangkapan kepiting bakau dengan kerapatan pohon mangrove pada lokasi penelitian menggambarkan bahwa hubungan kedua variabel sangat kuat dapat di lihat pada (Gambar 5).

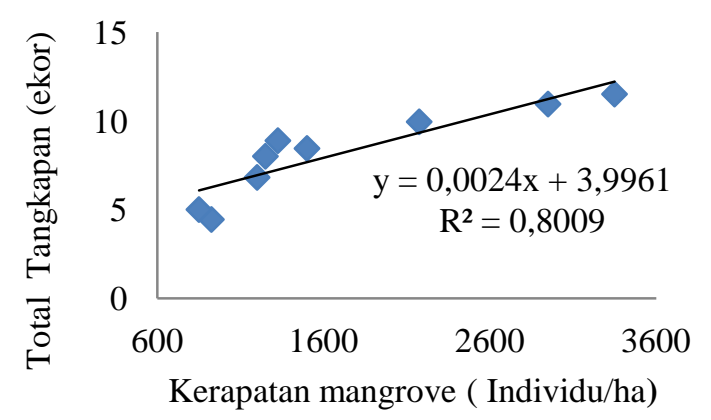

Gambar 5. Hubungan total tangkapan kepiting bakau dengan kerapatan pohon mangrove.
Dari hasil persamaan regresi sederahana yaitu $\mathrm{y}=0,002 \mathrm{x}+3,996$ dengan nilai koefisien determinasi $\left(\mathrm{R}^{2}\right)$ sebesar 0,800 ini artinya pengaruh kerapatan mangrove terhadap keberadaan kepiting sebesar $80 \%$, sedangkan nilai koefieien korelasi (r) di peroleh 0,89. Berdasarkan hasil regresi menunjukkan bahwa korelasi antara variabel kerapatan mangrove dan keberadaan kepiting bakau adalah sangat kuat. Menurut Sugiyono (2007) interpetasi koefisien korelasi 0,801,000 menandakan hubungan antara dua variabel sangat kuat.

\section{Hubungan Total Tangkapan Kepiting Bakau Dengan Kandungan C-Organik.}

Hubungan antara total tangkapan kepiting bakau dengan Kandungan COrganikpada lokasi penelitian menggambarkan bahwa hubungan kedua variabel sangat kuat dapat di lihat pada (Gambar 6).

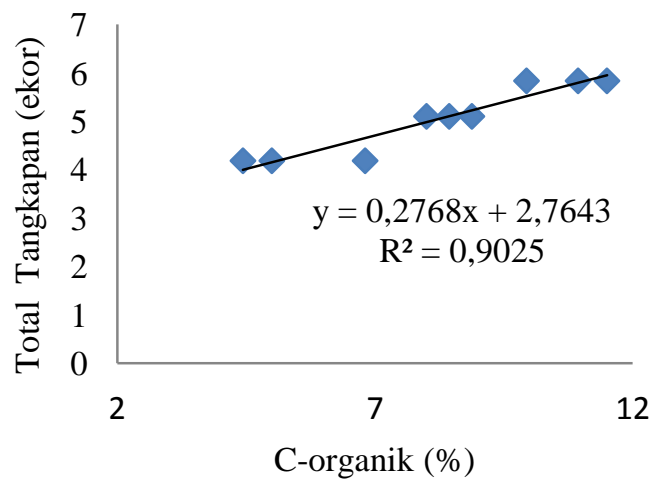

Gambar 6. Hubungan total tangkapan kepiting bakau dengan kandungan $\mathrm{C}$ Organik

Persamaan regresi sederahana yaitu y $=0,276 \mathrm{x}+2,764$ dengan nilai koefisien determinasi $\left(\mathrm{R}^{2}\right)$ sebesar 0,902 ini artinya pengaruh kandungan $\mathrm{C}$ - Organik terhadap keberadaan kepiting sebesar 90\%, sedangkan nilai koefieien korelasi (r) di peroleh 0,95.Berdasarkan hasil analisis regresi linier sederhana bahwa kepiting bakau memiliki hubungan yang kuat terhadap keberadaan kandungan C Organik.Menurut Sugiyono (2007) interpetasi koefisien korelasi 0,80-1,000 menandakan hubungan antara dua variabel sangat kuat. 


\section{KESIMPULAN}

1. Berdasarkan hasil pengamatan secara umum pada ekosistem mangrove di Kota Bengkulu memiliki potensi kepiting bakau

2. sebanyak 1.183 ekor dimana pada keraptan mangrove jarang 260 ekor, kerapatan mangrove sedang 405 dan kerapatan mangrove rapat 518 ekor. Dari keseluruhan total tangkapan kepiting pada fase juvenil 252 ekor, fase muda 859 dan fase dewasa 72 ekor. Terdapat 3 jenis kepiting bakau yaitu Scylla serrata, Scylla olivacea dan Scylla tranquibarica yang termasuk ke dalam Famili Portunidae, kelas Crustasea dan ordo Decapoda.

3. Secara keseluruhan habitat kepiting bakau pada perairan kota bengkulu sangat mendukung dalam menunjang kehidupan kepiting bakau dengan keberadaan kerapata mangrove jarang, sedang dan rapat yang memiliki 7 jenis mangrove yaitu yaitu R.apiculata,S.alba, B.gymnoriza, A.lanata, X.Granatum, K.candel dan $L$. littoreae. Memiliki kisaran parameter fisika kualitas air suhu $29,25^{\circ} \mathrm{C}$, salinitas $11-26,25^{\circ} \%, \mathrm{pH}$ 6,95-7,55 pasang tertinggi 80$106,25 \mathrm{~cm}$ dan kandungan COrganik 4,18-5,83\%.

4. Dari hasil analisis regresi linier sederhana adanya hubungan yang kuat antara kerapatan mangrove dengan kepiting bakau (Scylla spp). kandungan C-Organik dengan kepiting bakau (Scylla spp).

\section{DAFTAR PUSTAKA}

Bengen DG. 2000. Teknik Pengambilan Contoh dan Analisis Data Biofisik Sumberdaya Pesisir. Pusat Kajian
Sumberdaya Pesisir dan Lautan. InstitutPertanian Bogor.

BKSDA Bengkulu. 2013. Profil Kawasan Taman Wisata Alam Pantai Panjang Kota Bengkulu. Bengkulu. BKSDA Bengkulu Ditjen PHKA Kemenhut.

Brown, I.W. 1993. Mangrove Crabs, pp 609-42 in A. Wright and L. Hill (eds) Nearshore Marine Resources of the South Pacific. Institute of Pacific Studies (Suva), Forum Fisheries Agency (Honiara) and the International Centre for Ocean Development (Canada), 710p.

Hill, B. J. 1976. Natural food, foregut clearance-rate and activity of the crab Scylla serrata. Mar. Biol., 34: 109-116.

Kanna, I. 2002. Budidaya Kepiting Bakau Pembenihan dan Pembesaran. Kanisius. Yogyakarta.

Keenan, C. P and Blackshaw, A. 1998. Mud Crab Aquaculture and Biology. Australian Centre for International Agricultural Research. Canberra.

Kordi G. H. 2012. Jurus Jitu Pengelolaan Tambak untuk Budi Daya Perikanan Ekonomis. ANDI. Yogyakarta. $396 \mathrm{hlm}$.

Le Vay L. 2001. Ecology and management of mud crab Scylla spp. Asian Fisheries Sciense 14:101-111.

Pett, R. J. 1993. A collection of Laboratory Methods For Water and Sedimen Quality Parameter Report No. 13 International Development Program at Australia University and Colleges. PT. Husfarm Dian Konsultant. 20 p.

Siahainenia, L. 2008. Biologi Kepiting Bakau (Scylla spp.) di ekosistem mangrove. Kabupaten Subang, Jawa Barat. Sekolah Pascasarjana. Institute pertanian Bogor: 246 hal. 